\title{
ECONOMIC ANALYSIS OF COMMERCIAL ORGANIC AND CONVENTIONAL VEGETABLE FARMING IN KATHMANDU VALLEY
}

\author{
Kamal Shrestha ${ }^{1}$, Gautam Shrestha ${ }^{2}$, Pradyumna R.Pandey ${ }^{3}$
}

\begin{abstract}
Economics of a farming system is the key determinant of its sustainability. Organic and conventional farming systems are two distinct types of production systems having contrasting farm management practices and output price as well. Furthermore, organic farming system is promoted for environmental protection and conventional farming system is cursed for the environmental degradation. The present study was conducted to compare the economics of organic and conventional vegetable production in Kathmandu valley. Thirty farmers each involved in commercial organic and conventional vegetable farming were selected randomly for the study. Data were collected through survey method using semi-structured questionnaire. The estimated per ropani per year cost of cultivation of vegetables in the organic farm (NPR 69,170) was lesser than in conventional farm (NPR $1,00,562$ ). The gross return per ropani in a year in the organic vegetable farm (NPR $1,01,536)$ was significantly lesser than from conventional farms (NPR 1,35,747). Benefit to cost ratio $(B C R)$ was higher in organic farm (1.47:1) in comparison to conventional farm (1.35:1). This study revealed that organic vegetable farming was more profitable than conventional vegetable farming in Kathmandu valley. To expand commercial agriculture: quality inputs, input and output price stability, co-operative or corporative marketing should be promoted.
\end{abstract}

\section{INTRODUCTION}

Agriculture is the mainstay of the Nepalese economy. More than $65 \%$ households depend on agriculture for their livelihood generation (ABPSD, 2012a). Nevertheless, government investment in agriculture is not significantly increasing every year. The recent agricultural development strategy (ADS), which is yet to be endorsed from government level, has proposed to increase government expenditure in the agriculture sector (ADB 7762-NEP, 2013). The ADS has envisioned commercialisation of agriculture as the mean to uplift the national economy. Commercial periurban vegetable production is one of the recent developments in the Nepalese agriculture which aims to fulfil the urban population vegetable demand. Otherwise, the urban dwellers were dependent on the outsourced vegetables (Bhandari, 2006). Commercial vegetable production has generated employment opportunities as well as prevented the urban sprawling in the fertile lands (Shrestha, 2013).

Though traditional farming applying only organic manures in the field was an age old farming practice (MOAC, 2008); green revolution during 1960s promoted farmers to follow conventional farming (Shrestha, 2010). Conventional farming is the main vegetable production method supplying vegetables in Kathmandu valley.

\footnotetext{
${ }^{1}$ Himalayan College of Agricultural Sciences and Technology, email: shrestha_kamal11@yahoo.com ${ }^{2}$ Nepal Agricultural Research Council (NARC), Regional Agricultural Research Station, Khajura, Banke ${ }^{3}$ Ministry of Agricultural Development (MoAD)
} 
Conventional farming is defined as crop production practice applying petroleum based chemical fertiliser, chemical pesticide and growth stimulating chemical (MOAC, 2008). However, conventional farming results into soil biodiversity decline (Li et al. 2012), ecosystem imbalance (Wood et al. 2006), farmers' health compromise (Atreya et al. 2012) and soil fertility decline (Mader et al. 2002) in the long term. Hence, with acknowledging these facts, health conscious elite consumers (tourists, Upper class citizens) in the urban areas demanded for the organic vegetables (Bhatta et al. 2009). Organic farming is known as crop production without applying petroleum based chemical fertiliser, chemical pesticides and growth stimulating chemicals (Eyhorn et al. 2002; MOAC, 2008; Klonsky, 2012). Five star hotels demanded for the organic vegetables to serve their guests. Foreign personnel dwelling in Kathmandu valley also encouraged organic farming. Nowadays, there are commercial organic farmers, who are renowned for their organic vegetables in Kathmandu valley. New entrepreneurs are also joining organic farming. The ADS has envisioned organic produce export to the foreign market (ADB 7762-NEP, 2013).

In general, farmers initiate organic farming because organic produce get higher price premium in the market (Table 1). However, a farmer cannot sell their produce as an organic which is grown from the field with history of chemical fertiliser and pesticide use in the recent years. An organic farm must go through conversion period of at least three years to sell their produce as an organic one (Delbridge et al. 2011). At the same time, a farmer should test their soil and vegetables produced regularly to check if they are free of petroleum based chemical fertiliser and chemical pesticide residue. During conversion period, organic farm may fall into net loss (Bhatta et al. 2009; Sellen et al. 1995). Hence, government support during conversion period can boost organic farming adaptation (Welsh, 1999).

After conversion period, an organic produce need certification. Certification cost varies with the aimed market of the produce. If a farmer wants to sell produce within the country, it will cost lesser in comparison to the farmer who wants to export their produce to Europe or Japan.

Organic farm crop yield is lesser in comparison to conventional farm (Table 1). It is due to no use of petroleum based chemical fertiliser, growth hormone, genetically modified seed etc. in the organic farm (Kawasaki and Fujimoto, 2009) and pest and disease damage (de Ponti et al. 2012). Nevertheless, organic farm productivity increases in the long term (Mader et al. 2002). Organic farming is more laborious because an organic farmer needs to do frequent bulk manure application, mechanical weeding and disease and pest management to get good yield (Offermann and Nieberg, 2000; Delbridge et al. 2013).

Different studies have revealed mixed results for production cost of organic produce in comparison to conventional one (Table 1). Few studies have shown comparatively lower production cost for organic farming. It was due to availability of cheap labour in case of India (Naik et al. 2012) and subsidies available to the organic farmers in Europe (Offermann and Nieberg, 2000). In contrast, higher cost of manure purchase (Kawasaki and Fujimoto, 2009; Klonsky, 2012) and 
comparatively lower yield with same level of investment (Lien et al. 2007) resulted into higher production cost for organic produce.

Similarly, total return from organic farm can be relatively higher or lesser in comparison to the conventional farm (Table 1). As a consequence of lesser yield, keeping similar produce price results into lower revenue from organic farm (Adhikari, 2009; Naik et al. 2012). In contrast, Welsh (1997) reported possibility of higher profit in organic farming than in conventional farming without price premium as well. The same author mentioned lower production cost, higher net return and ability of drought tolerance by organic crops yield into higher profit than conventional farm. In general, a premium on organic produce keeps higher total return from organic farm in comparison to conventional farm (Offermann and Nieberg, 2000).

As production cost and total return showed mixed result, subsequent profit has also mixed figures (Table 1). Lesser profit from organic farming was due to higher cost of fertilisers, pesticides and labour and lesser yield in comparison to conventional farm (Sellen et al. 1995; Brumfield et al. 2000; Klonsky, 2012). On the contrary, in the developing countries where labour cost is cheap and organic manures are cheaper than chemical fertilisers make organic farming more profitable (Bhatta and Doppler, 2011) than conventional farming.

Nonetheless, many authors have revealed higher benefit to cost ratio for organic farming in comparison to conventional farming (Table 1). It happened because, gross return was relatively higher to the total production cost in the organic farm in comparison to the conventional one (Kawasaki and Fujimoto, 2009). Additionally, a premium for the organic produce contributed to this difference (Naik et al. 2012). On the contrary, Biswas et al. (2011) showed higher benefit to cost ratio in conventional farm in comparison to organic farm. It was due to significantly higher cost of organic manure input in organic farm than chemical fertiliser input in the conventional farm.

Though organic farming is an environmentally sustainable option (Mader et al. 2002); for a farmer it should be economically sustainable as well. Modelling study by Kavel (2004) presented conventional farming is more economically sustainable in comparison to organic farming. Nevertheless, consumers around the developed world are willing to pay premium price for organic products (Welsh, 1999). In addition, Kim et al. (2008) proposed Japan as a new potential market for organic produce where consumers are willing to pay $10 \%$ more price premium.

This study aims to give some insight about the economics of commercial organic and conventional vegetable farming in Kathmandu valley. This study will help farmers and investors to tight loop holes to increase the net profit from the commercial vegetable farming. 
Table 1. Review of literature on economic analysis of organic farming in comparison to conventional farming

\begin{tabular}{|c|c|c|}
\hline Particulars & $\begin{array}{l}\text { In comparison to } \\
\text { conventional farm* }\end{array}$ & Reference \\
\hline Seed & - & Adhikari (2009), Delbridge et al. (2011), Naik et al. (2012) \\
\hline Organic fertiliser & + & Adhikari (2009), Delbridge et al. (2011), Klonsky (2012) \\
\hline \multirow[t]{2}{*}{ Labour cost } & + & $\begin{array}{l}\text { Akomolafe (2000), Offermann and Nieberg (2000), Adhikari } \\
\text { (2009), Kawasaki and Fujimoto (2009), Läpple (2010), Klonsky } \\
\text { (2012), Delbridge et al. (2013) }\end{array}$ \\
\hline & - & Sellen et al. (1995), Canavari et al. (2007) \\
\hline \multirow{2}{*}{ Tillage } & - & Adhikari (2009) \\
\hline & + & Delbridge et al. (2011) \\
\hline Plant protection & - & Klonsky (2012) \\
\hline \multirow{2}{*}{$\begin{array}{l}\text { Total } \\
\text { cost }\end{array}$} & - & $\begin{array}{l}\text { Lockeretz et al. (1981), Akomolafe (2000), Adhikari (2009), } \\
\text { Bhatta and Doppler (2011), Delbridge et al. (2013) }\end{array}$ \\
\hline & + & Lien et al. (2007), Kawasaki and Fujimoto (2009) \\
\hline Land rent & - & Canavari et al. (2007) \\
\hline \multirow{2}{*}{ Production cost } & + & $\begin{array}{l}\text { Clark et al. (1999), Brumfield et al. (2000), Kavel (2004), Biswas } \\
\text { et al. (2011) }\end{array}$ \\
\hline & - & $\begin{array}{l}\text { Sellen et al. (1995), Offermann and Nieberg (2000), Mahoney et } \\
\text { al. (2004), Naik et al. (2012), Delbridge et al. (2011), }\end{array}$ \\
\hline \multirow[t]{2}{*}{ Yield } & - & $\begin{array}{l}\text { Lockeretz et al. (1981), Sellen et al. (1995), Offermann and } \\
\text { Nieberg (2000), Mader et al. (2002), Lien et al. (2007), Kawasaki } \\
\text { and Fujimoto (2009), Kuminoff and Wossink (2010), Biswas et } \\
\text { al. (2011), Seufert et al. (2012), Naik et al. (2012), de Ponti et } \\
\text { al. (2012), Delbridge et al. (2013) }\end{array}$ \\
\hline & + & Welsh (1999) \\
\hline Price premium & + & $\begin{array}{l}\text { Offermann and Nieberg (2000), Lien et al. (2007), Adhikari } \\
\text { (2009), Kawasaki and Fujimoto (2009) }\end{array}$ \\
\hline \multirow{2}{*}{ Total return } & - & Dobbs and Smolik (1996), Adhikari (2009) \\
\hline & + & $\begin{array}{l}\text { Chavas et al. (2009), Kuminoff and Wossink (2010), Naik et al. } \\
\text { (2012) }\end{array}$ \\
\hline \multirow[b]{2}{*}{ Profit } & - & Sellen et al. (1995), Rani et al. (2013) \\
\hline & + & $\begin{array}{l}\text { Delate et al. (2003), Mahoney et al. (2004), Smith et al. (2004), } \\
\text { Kerselaers et al. (2007), Bhatta and Doppler (2011), Delbridge } \\
\text { et al. (2011), Delbridge et al. (2013) }\end{array}$ \\
\hline \multirow{2}{*}{$\begin{array}{l}\text { Benefit to cost } \\
\text { ratio }\end{array}$} & + & $\begin{array}{l}\text { Adhikari (2009), Kawasaki and Fujimoto (2009), Naik et al. } \\
\text { (2012) }\end{array}$ \\
\hline & - & Biswas et al. (2011), Rani et al. (2013) \\
\hline
\end{tabular}

*'+' stands for comparatively higher value for organic farming than conventional farming and '-' stands for comparatively lower value for organic farming than conventional farming. 


\section{MATERIALS AND METHODS}

\section{STUDY AREA}

Kathmandu valley consists of three districts namely Kathmandu, Lalitpur and Bhaktapur. These districts are densely populated areas in Nepal (MEGA, 2010; Zurick and Rose, 2009). Vegetable production is an age old traditional farming practice near the water resources in Kathmandu valley. Kathmandu valley is one of the areas with the highest vegetable productivity per unit area in Nepal (ABPSD, 2012b). Moreover, increasing population and demand for fresh vegetables has increased the commercial vegetable farms in the suburbs. Furthermore, health conscious consumers in the city area are demanding for the organic vegetables; to supply the demand organic vegetable production area is also expanding (Bhandari, 2006). The periurban commercial vegetable growing farmers in Kathmandu valley were selected for the study.

\section{QUESTIONNAIRE SURVEY}

This work was conducted in sample group (SG) with 30 sample size of each type of farm but the soil type, and slope was not same. These differences may result into deviation in the required amount of inputs and changes in the output from place to place (Lee and Fowler, 2002). Thirty commercial farmers each growing vegetables following organic management methods and conventional management methods were selected for the study. Furthermore, we mainly considered commercial farmers doing off season vegetable production. Semi-structured questionnaire was prepared in Nepali language and pretested and amended before finalising for the survey. We intended to survey 10 each commercial organic and conventional farmer from a district. However, we did not find more than five commercial organic farmers in Bhaktapur district. So, we added five more organic farmers from Kathmandu district for the study. Farmers from Bhaktapur (15), Kathmandu (25) and Lalitpur (20) district were interviewed to gather information on economic aspects of the farm management. Questionnaire survey was conducted during May 15 to June 15, 2013.

\section{DATA ANALYSIS}

Financial aspects of organic vegetable production were compared with that of conventional vegetable production by Independent samples $\mathrm{T}$ test. Problem related to market of organic and conventional vegetable farm were ranked using index developed by Miya (1993). The index was prepared mainly taking into account the qualitative data. On the basis of response frequencies, weighted indexes were calculated. The intensity of farmers problems were identified by using five point scaling technique comprising 'most serious', 'serious', 'moderate', 'a little bit' and 'no problem at all' using scores of 5, 4, 3, 2 and 1 respectively. Then the priority index for each variable was calculated by weightage average mean in order to draw a valid conclusion.

The intensity of problem was computed by using the formula:

$$
I_{p \operatorname{mab}}=\sum \frac{s_{i} \bar{F}_{i}}{N}
$$


Where,

$$
\begin{array}{ll}
\mathrm{I}_{\text {prob }} & =\text { Index value for intensity of problem } \\
\Sigma & =\text { Summation } \\
\mathrm{S}_{\mathrm{i}} & =\text { Scale value of } \mathrm{i}^{\text {th }} \text { intensity } \\
\mathrm{F}_{\mathrm{i}} & =\text { Frequency of } \mathrm{i}^{\text {th }} \text { response } \\
\mathrm{N} & =\text { Total number of respondents }
\end{array}
$$

\section{RESULTS}

\section{CROPPING SYSTEM}

Comparatively organic farmers grew more crops at a time than conventional farmers (Table 2). Tomato, pumpkin, cauliflower, cabbage, chilli, bitter gourd, brinjal and coriander were the main crops cultivated as the main crops by both organic and conventional farmers in the survey.

Among organic farmers, prevalent intercropping practices were brinjal and cabbage, cabbage and garlic, broccoli and knolkhol, french-bean and pumpkin. With organic tomato production, mixed crops were carrot, cowpea, celery, and pumpkin.

In conventional farm, major intercrops with tomato were cauliflower, frenchbean, radish and turnip. The major mixed crops with tomato were coriander, broad leaf mustard and pumpkin.

Table 2. Cropping systems followed by commercial organic and conventional vegetable growers (percentage respondents out of 30 each) in Kathmandu valley

\begin{tabular}{lcc} 
Cropping systems & Organic farmers & Conventional farmers \\
\hline Mono cropping & 43.3 & 63.3 \\
Mixed cropping & 30.0 & 23.3 \\
Inter cropping & 26.7 & 13.3 \\
\hline
\end{tabular}

\section{PROFITABILITY ANALYSIS OF VEGETABLE PRODUCTION}

Commercial vegetable farmers in Kathmandu valley were on an average investing NPR 1,00,000 per ropani in a year. Investment amount was significantly lesser in the organic farm (NPR 70,000) than conventional farm (NPR 1,15,000) (Table 3).

Total production cost in organic farm was lesser due to significantly lesser plant protection cost, transportation cost and depreciation cost. Lesser fertiliser cost in organic farm was due to no use of chemical fertiliser and use of significantly lesser amount of chicken manure. Conventional vegetable farmers were applying significantly higher amount of chicken manure than organic farmers. Conventional farmers were spending comparable amount of money in organic fertiliser input to that of organic farmers (Table 3 ). 
Seasonal requirement of labour was significantly higher in the organic farm (NPR 1,800 ) in comparison to the conventional farm (NPR 500) for a ropani in a year (Table 3). Permanent labour use was relatively higher in the conventional farm (NPR 15,000) in comparison to the organic farm (NPR 10,000) per ropani per year. With higher yield in the conventional farm, gross return was significantly higher in the conventional farm (NPR 1,35,000) than in the organic farm (NPR $1,00,000)$ from a ropani vegetable field in a year. Net profit from commercial vegetable farming in both organic and conventional farms was on an average NPR 30,000 per ropani per year. Maximum profit was obtained from conventional farm (NPR 55,000) than organic farm (NPR 40,000) (Table 3). On an average benefit to cost ratio for organic farm was relatively higher (1.47:1) than in the conventional farm (1.35:1) (Table 3).

\section{TYPES OF MARKETING}

Both organic and conventional farmers were selling their vegetable via different marketing methods (Figure 1). The most popular marketing method in both types of farms was self- marketing. In this method of marketing, farmers took their vegetables in the market and sold to either customer or shopkeeper. Farmers also sold their vegetables directly to the consumers who visited their farms. It was the least popular method of selling vegetable in the conventional farms (Figure 1).

Both organic and conventional farmers channelled their vegetables to market from middle man come to the farms. Selling vegetables in the local market was the least used method by organic farmers since they face problem of lesser or no price premium in the local market (Figure 1).

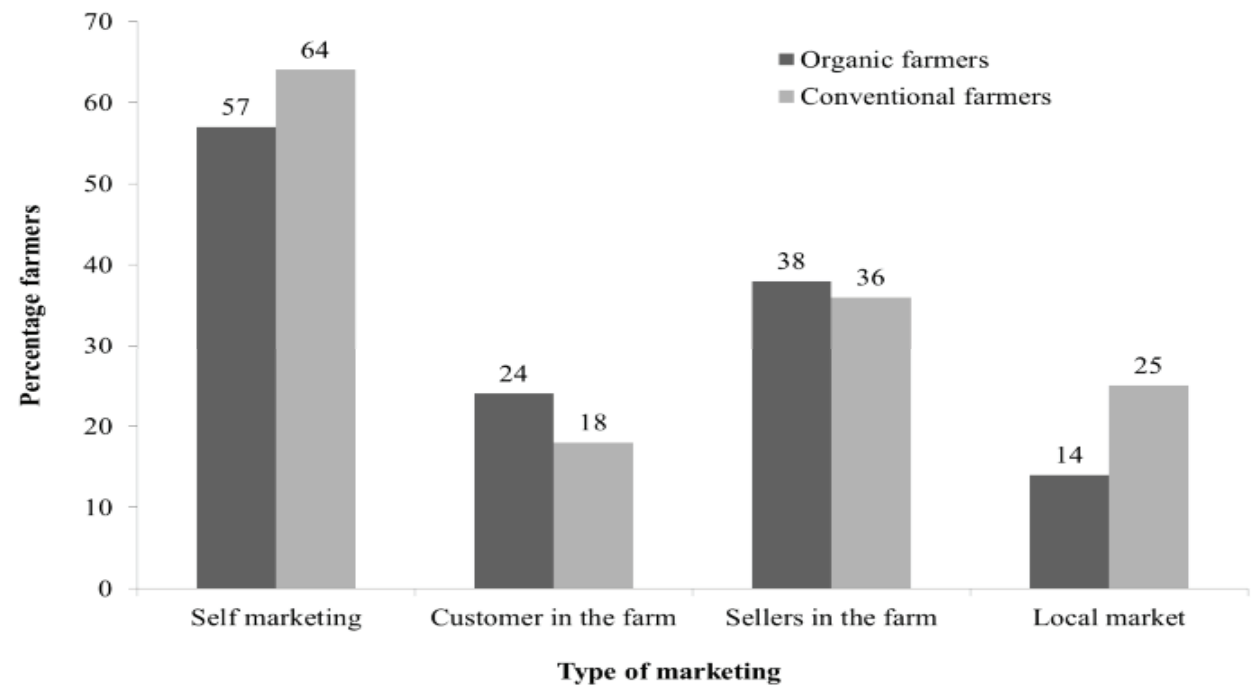

Figure 1. Types of marketing followed by organic and conventional farmers in Kathmandu valley 


\section{PROBLEMS}

Regarding the marketing aspects, the most serious marketing problem faced by both organic and conventional farmers was vegetable price instability (Table 4). Among organic farmers, the second major market related problem was input price instability. For conventional farmers, higher middleman margins were the second most important problem (Table 4).

Table 3. Profitability analysis of vegetable production in commercial organic and conventional farms in Kathmandu valley (mean \pm standard error, NPR per ropani per year)

\begin{tabular}{|c|c|c|c|}
\hline \multicolumn{2}{|c|}{ Particulars } & Organic farm & Conventional farm \\
\hline \multirow{19}{*}{ 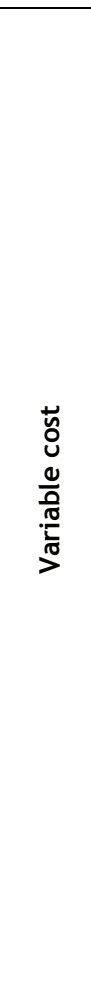 } & Seed & $1,037.93 \pm 66.60$ & $1,370.52 \pm 227.50$ \\
\hline & Hired labour & $1,830.62 \pm 492.44^{* *}$ & $456.10 \pm 227.45^{* *}$ \\
\hline & Family labour & $19,055.43 \pm 2,577.64$ & $18,029.10 \pm 3,368.76$ \\
\hline & Permanent labour & $10,111.97 \pm 2,745.78$ & $15,096.11 \pm 2,462.37$ \\
\hline & Total labour & $30,998.02 \pm 2,538.52$ & $33,581.31 \pm 3,655.13$ \\
\hline & A. Chemical fertiliser & - & $1,189.82 \pm 155.17$ \\
\hline & Urea & - & $312.20 \pm 39.99$ \\
\hline & DAP & - & $594.58 \pm 95.92$ \\
\hline & MoP & - & $283.05 \pm 45.56$ \\
\hline & B. Organic fertiliser & $9,166.30 \pm 1564.08$ & $9,651.83 \pm 1471.10$ \\
\hline & Poultry manure & $1,648.17 \pm 358.51^{*}$ & $3,407.79 \pm 893.57^{*}$ \\
\hline & Farmyard manure & $1,975.22 \pm 427.02$ & $3,294.27 \pm 754.37$ \\
\hline & Urban compost & $1,782.77 \pm 593.99^{* *}$ & $242.56 \pm 111.72^{* *}$ \\
\hline & Mustard cake & $812.64 \pm 257.71$ & $567.17 \pm 122.25$ \\
\hline & Bone meal & $404.26 \pm 132.65$ & $237.52 \pm 84.61$ \\
\hline & Compost mix & $2,543.25 \pm 1055.49$ & $1,902.52 \pm 408.99$ \\
\hline & Total fertiliser $(A+B)$ & $9,166.30 \pm 1,564.07$ & $10,841.65 \pm 1,489.40$ \\
\hline & Plant protection & $1,921.37 \pm 77.73^{* *}$ & $4,473.21 \pm 471.25^{* *}$ \\
\hline & Transportation & $1,339.29 \pm 4.29^{* *}$ & $2,452.84 \pm 224.54^{* *}$ \\
\hline \multirow{4}{*}{ 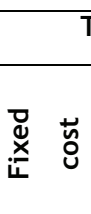 } & al variable cost & $34,350.94 \pm 2789.04$ & $37,623.43 \pm 3,700.07$ \\
\hline & Land rent & $10,169.98 \pm 777.77$ & $11,166.20 \pm 529.60$ \\
\hline & Interest on loan & $2,390.60 \pm 1,249.80$ & $17,554.40 \pm 15,099.40$ \\
\hline & Depreciation & $12,146.56 \pm 955.17^{* *}$ & $19,122.26 \pm 1,883.51^{* *}$ \\
\hline \multicolumn{2}{|c|}{ Total fixed cost } & $34,819.11 \pm 3519.81$ & $62,938.98 \pm 17,686.12$ \\
\hline \multicolumn{2}{|c|}{ Total cost } & $69,170.05 \pm 3,929.50^{*}$ & $1,00,562.41 \pm 17,235.46^{*}$ \\
\hline \multicolumn{2}{|c|}{ Gross return } & $1,01,536.09 \pm 9,736.89^{*}$ & $1,35,747.79 \pm 14,774.01^{*}$ \\
\hline \multicolumn{2}{|c|}{ Gross margin } & $67,185.20 \pm 9,489.98^{*}$ & $98,124.34 \pm 15,492.44^{*}$ \\
\hline \multicolumn{2}{|c|}{ Net margin } & $32,366.09 \pm 8619.17$ & $35,185.36 \pm 21,393.38$ \\
\hline \multicolumn{2}{|c|}{ Benefit to cost ratio } & $1.47: 1$ & $1.35: 1$ \\
\hline
\end{tabular}


*, ** Values were significantly different between two farming systems at $\mathrm{p}$ value $\left({ }^{*}\right.$ for $\left.<0.05,{ }^{* *}<0.01\right)$ when tested with independent samples t test; Urea $(46 \% \mathrm{~N})$; DAP = diammonium phosphate (18\% N and $46 \% \mathrm{P})$; MoP = Muriate of potassium $(60 \% \mathrm{~K})$; Compost mix $=$ mixture of two or more manures i.e. poultry manure, compost, mustard cake, bone meal etc.

Table 4. Market related problems among commercial organic and conventional vegetable farmers in Kathmandu valley

\begin{tabular}{lcc|cc}
\hline \multirow{2}{*}{ Market related problems } & \multicolumn{2}{c|}{ Organic farm } & \multicolumn{2}{c}{ Conventional farm } \\
\cline { 2 - 5 } & Index value* $^{*}$ & Rank & Index value* & Rank \\
\hline Transportation and road & 1.889 & 7 & 1.767 & 8 \\
Price information & 2.926 & 5 & 2.733 & 4 \\
Vegetable price instability & 3.259 & 1 & 3.867 & 1 \\
Available market & 2.630 & 6 & 2.167 & 6 \\
Assurance of getting income & 1.852 & 8 & 1.759 & 9 \\
Inputs price instability & 3.148 & 2 & 2.400 & 5 \\
Premium price of produce in the local market & 3.115 & 3 & 2.833 & 3 \\
Middleman margins & 3.000 & 4 & 3.500 & 2 \\
Storage facility & 1.407 & 9 & 1.867 & 7 \\
\hline
\end{tabular}

* Index value range from 5 to 1 , where $5=$ most serious, $4=$ serious, $3=$ moderate, $2=$ little bit and $1=$ no problem at all

SWOT ANALYSIS

Organic vegetable farming was more profitable than conventional vegetable farming in Kathmandu valley. Commercial vegetable farming has created employment opportunities as well. Though Kathmandu valley is the centre of country, lack of quality and variety inputs was still the weakness to be solved for higher productivity (Table 5).

Urban compost produced can be better used in commercial vegetable farms promoting the internal recycling of nutrients. However, mono-cropping and lack of crop rotation etc. are the features of the commercial vegetable production which lead to the higher incidence of diseases and pests. As a threat, decrease in the vegetable price can lead to financial loss to the farmers (Table 5).

Table 5. SWOT analysis of commercial vegetable farming in Kathmandu valley

\begin{tabular}{|c|c|}
\hline Strength (S) & Weakness (W) \\
\hline $\begin{array}{l}\text { Vegetable farming in Kathmandu valley is } \\
\text { profitable. Organic vegetable farming is more } \\
\text { profitable than conventional farming. } \\
\text { Better employment opportunities. }\end{array}$ & $\begin{array}{l}\text { - } \quad \text { Lack of appropriate crop varieties. } \\
\text { - } \quad \text { Poor quality seeds and fertiliser. } \\
\text { - High middleman margins. }\end{array}$ \\
\hline Opportunity (0) & Threat (T) \\
\hline $\begin{array}{l}\text { - } \quad \text { Shifting from subsistence to commercial } \\
\text { vegetable production. } \\
\text { - } \quad \text { Use of urban waste. } \\
\text { - Transform conventional vegetable farming to } \\
\text { organic vegetable farming. }\end{array}$ & $\begin{array}{l}\text { - } \quad \text { More incidences of disease and pests requirir } \\
\text { high use of pesticides leading to high } \\
\text { production cost. } \\
\text { - } \quad \text { Fluctuation in market prices of inputs as well } \\
\text { as vegetable produce. } \\
\text { - } \quad \text { Labour shortage. }\end{array}$ \\
\hline
\end{tabular}




\section{DISCUSSIONS}

\section{COST OF PRODUCTION}

The expense on seed was not so different between two farming systems (Table 3), as quality seed determines the production level (Tiedemann and Latacz-Lohmann, 2013). Though non-significant, on par with Adhikari (2009), Delbridge et al. (2011) and Naik et al. (2012) our results showed lesser cost for seed procurement in organic farm in comparison to conventional farm. It was maybe due to use of expensive high yielding hybrid varieties in conventional farms and relatively less expensive disease resistant varieties in the organic farms (Murphy et al. 2007).

Agreeing with Akomolafe (2000), Offermann and Nieberg (2000), Adhikari (2009), Kawasaki and Fujimoto (2009) and Läpple (2010) our result confirmed that significantly higher labour cost in the organic farming in comparison to the conventional farming. It was due to the requirement of frequent application of organic pesticides in the organic fields, mechanical management of disease, pest and weed, and care to the soil environment (Kawasaki and Fujimoto, 2009). It was also due to more intercropping and mixed cropping practice in organic farming (Table 2) where crops need different cultural practices at dissimilar time. Moreover, availability of labour determines the vegetable yield of organic farms (Tiedemann and Latacz-Lohmann, 2013).

Poultry manure application was significantly higher in the conventional commercial vegetable farming. It was due to significant role of poultry manure in yield by adding chiefly nitrogen nutrients (Ghosh et al. 2004). Additionally, poultry industry establishments around Kathmandu valley have also increased the poultry manure input in the farmlands. However, for organic farmers poultry manure was relatively more expensive manure in comparison to farmyard manure and urban compost. Hence, amount of application was lesser in the organic fields.

Urban compost application was significantly higher in the organic farm in comparison to the conventional vegetable farm. It was because cheap available organic manure source in Kathmandu valley was urban compost.

Agreeing with Klonsky (2012), plant protection expenses in the organic farm was significantly lesser in comparison to the conventional farm. Pesticide shops recommend multiple chemical pesticides for a disease or pest problem without identifying the specific cause; leading to higher plant protection cost in the conventional farms. In contrast, there were very few commercially available organic disease and pest management products in the Kathmandu valley market. Many organic farmers used raw plant materials to prepare organic pesticides. Others were doing mechanical disease and pest management. 
Though insignificant, there was large difference in the interest on loan amount between organic and conventional farmers (Table 3 ). Only $15 \%$ organic farmers have taken loan once they have started their farming; loan amount ranging from NPR $2,00,000$ to $15,00,000$. About $30 \%$ conventional farmers have taken loan of amount NPR 35,000 to $1,50,00,000$. Conventional farmers have taken loan to build plastic tunnel for off season tomato cultivation. In comparison to organic farmers, conventional farmers have invested almost three times higher amount (NPR 16,000 per ropani) in plastic tunnel construction. Moreover, as the conventional farm size was larger (18 ropani) than organic farm (11 ropani), conventional farmers need more money at the start of the farming to invest. Commercial farmers have taken loan from bank, co-operative and individual with interest rate of $12 \%$ to $36 \%$.

Depreciation cost was significantly higher in the conventional farm in comparison to the organic farm. Relatively large farm size, plastic tunnel, accessories used for pesticide application etc. has increased fixed cost in conventional farm and so was depreciation cost (Table 3 ).

\section{MARKETING}

The cost of transportation was significantly lesser for the organic produce than that for the conventional produce. It was due to proximity to the market and assured consumers for organic vegetables. Furthermore, formation of producer association and co-operative marketing can further decrease the cost of transportation (Hattam and Holloway, 2007).

Higher middleman margins were the cause of less earning in the commercial farms (Table 4). This problem was more pronounced due to lack of corporate marketing practice (Kawasaki and Fujimoto, 2009). From figure 1, it was observed that cooperative and/or corporate marketing is not in practice among commercial farmers.

Premium obtained for organic produce was able to cover the lower yield from organic farm. Additionally, production cost in the organic farm was lesser than in the conventional farm. Hence, organic farm has higher benefit to cost than conventional farm. However, in this financial analysis, the cost of organic certification was not included.

\section{CONCLUSIONS}

Commercial vegetable farming is a profitable enterprise in Kathmandu valley. It is because of ease of the market and inputs. Economic analysis showed that both commercial organic and conventional farming had benefit to cost ratio of higher than $1: 1$. However, price instability of both inputs and vegetables put commercial farmers in the risk of getting into financial loss. Though ease of market and about $20 \%$ consumers come to the farm, other $80 \%$ consumers get vegetables from the middle man who makes profit even more than the vegetable producer.

In the case of commercial organic vegetable production, price premium is the main factor yielding higher benefit to cost ratio than conventional farming though lower yield. Additionally, the production cost was lower in the organic vegetable farming in comparison to conventional vegetable farming. For future, more 
conventional farmers in the suburbs of Kathmandu valley have opportunity to shift to organic vegetable production. Commercial farmers should initiate co-operative or corporate marketing for more benefit to the righteous persons (both producers and consumers).

\section{ACKNOWLEDGEMENTS}

The authors are grateful to the University Grants Commission (UGC), Nepal for providing financial support to conduct this research. We are indebted to all the respondent farmers for their precious time and invaluable time to answer the questionnaires. We acknowledge anonymous reviewer for constructive suggestions to bring the manuscript in this stage. The first and second authors have contributed equal in the manuscript preparation.

\section{REFERENCES}

ABPSD. 2012a. Statistical information on Nepalese agriculture 2011/12. Singha Durbar, Kathmandu: Agri Statistics Section, Agri-Business Promotion and Statistics Division (ABPSD), Ministry of Agricultural Development.

ABPSD. 2012b. Vegetable farming technology (in Nepali). Singha Durbar, Kathmandu: Agribusiness Promotion and Statistics Division (ABPSD), Ministry of Agricultural Development, Government of Nepal.

ADB 7762-NEP. 2013. Preparation of the Agricultural Development Strategy (ADS): Final report. Kathmandu: Asian Development Bank (ADB).

Adhikari, R. K., 2009. Economics of organic vs inorganic carrot production in Nepal. Journal of Agriculture and Environment, 10: 27-33.

Akomolafe, B. A., 2000. Comparative economic analysis of organic and inorganic farming methods in Ondo State, Nigeria. Master degree thesis, Federal University of Technology, Akure, Nigeria.

Atreya, K., Johnsen, F. H., and Sitaula, B. K., 2012. Health and environmental costs of pesticide use in vegetable farming in Nepal. Environmental Development and Sustainability, 14: 477-493.

Bhandari, D. R., 2006. Community level organic vegetable production program: an experience of Kathmandu district. Paper presented at the Proceedings of a first national workshop on organic farming, 12 to 14 June (Baisakh 28 - 30, 2063 B.S.), Kirtipur, Kathmandu.

Bhatta, G. D., Doppler, W., and Shrestha, G., 2009. Changing agriculture land use practice towards organic in peri-urban areas of Nepal: through producers and consumers perspective. Paper presented at the Proceedings of International Symposium on Environment, Energy and Water in Nepal: Recent Researches and Direction for Future, Kathmandu.

Bhatta, G. D., and Doppler, W., 2011. Smallholder peri-urban organic farming in Nepal: A comparative analysis of farming systems. Journal of Agriculture, Food Systems and Community Development, 1(3): 163-180.

Biswas, R. K., Majumder, D., and Sinha, A., 2011. Impacts and constraints evaluation of organic farming in West Bengal. Visva-Bharati, Santiniketan: Agro-Economic Research Centre.

Brumfield, R. G., Rimal, A., and Reiners, S., 2000. Comparative cost analyses of conventional, integrated crop management, and organic methods. HortTechnology, 10(4): 785-793.

Canavari, M., Ghelfi, R., Olson, K. D., and Rivaroli, S., 2007. A comparative profitability analysis of organic and conventional farms in Emilia-Romagna and in Minnesota. Organic Food (pp. 31-45): Springer.

Chavas, J. P., Posner, J. L., and Hedtcke, J. L., 2009. Organic and conventional production systems in the Wisconsin Integrated Cropping Systems Trial: II. Economic and risk analysis 1993-2006. Agronomy Journal, 101(2): 288-295.

Clark, S., Klonsky, K., Livingston, P., and Temple, S., 1999. Crop-yield and economic comparisons of organic, low-input, and conventional farming systems in California's Sacramento Valley. American Journal of Alternative Agriculture, 14(3): 109-121. 
de Ponti, T., Rijk, B., and van Ittersum, M. K., 2012. The crop yield gap between organic and conventional agriculture. Agricultural systems, 108: 1-9.

Delate, K., Duffy, M., Chase, C., Holste, A., Friedrich, H., and Wantate, N., 2003. An economic comparison of organic and conventional grain crops in a long-term agroecological research (LTAR) site in lowa? American Journal of Alternative Agriculture, 18(2): 59-69.

Delbridge, T. A., Coulter, J. A., King, R. P., Sheaffer, C. C., and Wyse, D. L., 2011. Economic performance of long-term organic and conventional cropping systems in Minnesota. Agronomy Journal, 103(5): 1372-1382.

Delbridge, T. A., Fernholz, C., King, R. P., and Lazarus, W., 2013. A whole-farm profitability analysis of organic and conventional cropping systems. Agricultural systems, 122: 1-10.

Dobbs, T. L., and Smolik, J. D., 1996. Productivity and profitability of conventional and alternative farming systems: a long-term on-farm paired comparison. Journal of Sustainable Agriculture, 9(1): 63-79.

Eyhorn, F., Heeb, M., and Wieidmann, G., 2002. IFOAM Training manual for organic agriculture in the Tropics: Theory, transparencies, didactic apporach. : International federation of organic agriculture movements (IFOAM), Research institute of organic agriculture (FiBL), CABI Bioscience, Agrecol Afique (Senegal), Agrecol Andes (Bolivia) and INOCERT (India).

Ghosh, P., Ramesh, P., Bandyopadhyay, K., Tripathi, A., Hati, K., Misra, A., and Acharya, C., 2004. Comparative effectiveness of cattle manure, poultry manure, phosphocompost and fertilizer-NPK on three cropping systems in vertisols of semi-arid tropics. I. Crop yields and system performance. Bioresource Technology, 95(1): 77-83.

Hattam, C., and Holloway, G., 2007. Bayes estimates of time to organic certification. Paper presented at the Annual Conference of the Agricultural Economics Society, University of Reading, UK.

Kerselaers, E., De Cock, L., Lauwers, L., and Van Huylenbroeck, G., 2007. Modelling farmlevel economic potential for conversion to organic farming. Agricultural Systems, 94(3): 671-682.

Kavel, P., 2004. The profitability of alternative cropping systems: a review of the literature. Journal of Sustainable Agriculture, 23(3): 47-65.

Kawasaki, J., and Fujimoto, A., 2009. Economic and technical assessment of organic vegetable farming in comparison with other production systems in Chiang Mai, Thailand. Journal of ISSAAS [International Society for Southeast Asian Agricultural Sciences], 15(1): 144-169.

Kim, R., Suwannamek, O., and Toyoda, T., 2008. Consumer attitude towards organic labelling schemes in Japan. Journal of International Food and Agribusiness Marketing, 20(3): 55-71.

Klonsky, K., 2012. Comparison of production costs and resource use for organic and conventional production systems. American Journal of Agricultural Economics, 94(2): 314-321.

Kuminoff, N. V., and Wossink, A., 2010. Why isn't more US farmland organic? Journal of Agricultural Economics, 61(2): 240-258.

Läpple, D., 2010. Adoption and abandonment of organic farming: an empirical Investigation of the Irish drystock sector. Journal of Agricultural Economics, 61(3): 697-714.

Lee, H., and Fowler, S., 2002. A critique of methodologies for the comparison of organic and conventional farming systems. Paper presented at the Proceedings of the UK Organic Research 2002 Conference.

Li, R., Khafipour, E., Krause, D. O., Entz, M. H., de Kievit, T. R., and Fernando, W. D., 2012. Pyrosequencing reveals the influence of organic and conventional farming systems on bacterial communities. PloS One, 7(12): e51897.

Lien, G., Hardaker, J. B., and Flaten, O., 2007. Risk and economic sustainability of crop farming systems. Agricultural Systems 94: 541-552. 
Lockeretz, W., Shearer, G., and Kohl, D. H., 1981. Organic farming in the Corn Belt. Science, 211(4482): 540-547.

Mahoney, P. R., Olson, K. D., Porter, P. M., Huggins, D. R., Perillo, C. A., and Kent Crookston, R., 2004. Profitability of organic cropping systems in southwestern Minnesota. Renewable Agriculture and Food Systems, 19(01): 35-46.

Mader, P., FlieBbach, A., Vubois, D., Gunst, L., Fried, P., and Niggli, U., 2002. Soil fertility and biodiversity in organic farming. Science, 296: 1694-697.

MEGA. 2010. District profile 2010. Kathmandu: Mega Research Centre and Publication (MEGA).

Miȳa, M. A. K., 1993. Applied Statistics: A course handbook for human settlements planning: Division of Human Settlements Development, Asian Institute of Technology.

MoAC. 2008. Nepalese standards of organic agriculture. Kathmandu, Nepal: Ministry of Agriculture and Cooperative (MoAC), Government of Nepal.

Murphy, K. M., Campbell, K. G., Lyon, S. R., and Jones, S. S., 2007. Evidence of varietal adaptation to organic farming systems. Field Crops Research, 102(3): 172-177.

Naik, V., Kunnal, L., Patil, S., and Guledgudda, S., 2012. Organic and inorganic cultivation of chilli and its marketing-an economic analysis. Karnataka Journal of Agricultural Sciences, 25(2): 203-207.

Offermann, F., and Nieberg, H., 2000. Economic performance of organic farms in Europe: Universität Hohenheim, Institut für Landwirtschaftliche Betriebslehre.

Rani, S., Khan, M. A., Shah, H., and Anjum, A. S., 2013. Profitability analysis of organic cauliflower, radish and turnip produce at national agriculture research centre, Islamabad, Pakistan. Asian Journal of Agriculture and Rural Development, 3(12): 929935.

Sellen, D., Tolman, J. H., McLeod, D. G. R., Weersink, A., and Yiridoe, E. K., 1995. Comparison of financial returns during early transition from conventional to organic vegetable production. Journal of Vegetable Crop Production, 1(2): 11-39.

Seufert, V., Ramankutty, N., and Foley, J. A., 2012. Comparing the yields of organic and conventional agriculture. Nature, 485(7397): 229-232.

Shrestha, G., 2013. Decreased organic manure application in Kathmandu valley vegetable fields threatens the soil productivity. Nepalese Journal of Agricultural Sciences, 11: 62-70.

Shrestha, R. K., 2010. Fertilizer policy development in Nepal. The Journal of Agriculture and Environment, 11: 126-137.

Smith, E. G., Jill Clapperton, M., and Blackshaw, R. E., 2004. Profitability and risk of organic production systems in the northern Great Plains. Renewable Agriculture and Food Systems, 19(03): 152-158.

Tiedemann, T., and Latacz-Lohmann, U., 2013. Production risk and technical efficiency in organic and conventional agriculture-the case of arable farms in Germany. Journal of Agricultural Economics, 64(1): 73-96.

Welsh, R., 1999. The economics of organic grain and soybean production in the Midwestern United States. Policy Studies Program Reports.

Wood, R., Lenzen, M., Dey, C., and Lundie, S., 2006. A comparative study of some environmental impacts of conventional and organic farming in Australia. Agricultural Systems, 89(2): 324-348.

Zurick, D., and Rose, A., 2009. Landscape change in Kathmandu valley, Nepal. Focus on Geography, 51(4): 7-16. 